Article

\title{
Syntheses of Benzo[d]Thiazol-2(3H)-One Derivatives and Their Antidepressant and Anticonvulsant Effects
}

\author{
Qinghao Jin ${ }^{1}$, Zhiyang Fu ${ }^{2}$, Liping Guan ${ }^{2, *} \mathbb{C}$ and Haiying Jiang ${ }^{3, *}$ \\ 1 Donghai Science and Technology College, Zhejiang Ocean University, Zhoushan 316000, China \\ 2 Food and Pharmacy College, Zhejiang Ocean University, Zhoushan 316022, China \\ 3 College of Medicine, Jiaxing University, Jiaxing 314001, China \\ * Correspondence: glp730@163.com (L.G.); jiangyang7689@aliyun.com (H.J.); Tel.: +86-580-2555280 (L.G.); \\ $+86-573-83643808$ (H.J.)
}

Received: 4 July 2019; Accepted: 19 July 2019; Published: 23 July 2019

check for updates

\begin{abstract}
Thirty-four new benzo[ $d]$ thiazol derivatives $\mathbf{2 a} \mathbf{a}-\mathbf{2} \mathbf{i}, \mathbf{3 a}-\mathbf{3 r}$, and $\mathbf{4 a}-\mathbf{4} \mathbf{g}$ were synthesized and investigated for their potential antidepressant and anticonvulsant effects. In a forced swimming test, $\mathbf{2 c}$ and $\mathbf{2 d}$ showed the highest antidepressant and anticonvulsant effects. $\mathbf{2 c}$ and $\mathbf{2 d}$ displayed a higher percentage decrease in immobility duration $(89.96 \%$ and $89.62 \%$, respectively) than that of fluoxetine $(83.62 \%)$. In the maximal electroshock seizure test, $3 \mathrm{n}$ and $3 \mathbf{q}$ showed the highest anticonvulsant effect, with $\mathrm{ED}_{50}$ values of 46.1 and $64.3 \mathrm{mg} \mathrm{kg}^{-1}$, and protective indices of 6.34 and 4.11 , respectively, which were similar to those of phenobarbital or valproate. We also found that the mechanism for the antidepressant activity of $\mathbf{2 c}$ and $\mathbf{2 d}$ may be via increasing the concentrations of serotonin and norepinephrine.
\end{abstract}

Keywords: benzo[d]thiazol; synthesis; antarctic-derived fungus; antidepressant; anticonvulsant

\section{Introduction}

During selective evolution, microorganisms in the polar region are distinct from other microorganisms with respect to genomic composition and have unique molecular-biological mechanisms, including metabolic regulation. Tan et al. reported very rich microbial resources in the Arctic and Antarctic [1]. In addition to extremely high species diversity [2], the structures of secondary metabolites of polar microbes also show diversity. Therefore, the Arctic and Antarctic regions are considered to be valuable natural products pools.

In an investigation of the secondary metabolites of the Antarctic-derived fungus Penicillium sp. $44.42^{\circ} \mathrm{W}, 60.54^{\circ} \mathrm{S}, 239 \mathrm{~m}$ underwater, water temperature of $-1.16^{\circ} \mathrm{C}$ ), Jiao et al. reported the isolation of nine compounds from the fermentation broth of Penicillium sp. [3], including benzo[d]thiazol-2(3H)-one (Figure 1). Benzothiazoles are heterocyclic aromatic hydrocarbons containing phenyl and thiazole rings, as well as sulfur and nitrogen atoms in their structures. Benzothiazole derivatives display a wide spectrum of pharmacologic effects, including anti-inflammatory [4], antibacterial [5], antiviral [6], antioxidant [7], and immunomodulatory properties [8]. In addition to the central nervous system (CNS)-related pharmacologic effects, benzothiazole compounds have been reported to display selective inhibitory effects against monoamine oxidase [9-12], as well as anti-Alzheimer's disease [13] and convulsions [14]. The antidepressant effect of a series of benzothiazole derivatives has been demonstrated through animal models such as the tail suspension test (TST) and forced swimming test (FST) $[15,16]$.

Several reports have described the antidepressant and anticonvulsant activities of benzothiazole derivatives $[15,16]$. For this reason, we synthesized thirty-four new benzo[ $d]$ thiazole derivatives $\mathbf{2 a}-\mathbf{2} \mathbf{i}$, $\mathbf{3 a}-\mathbf{3 r}$ and $\mathbf{4 a - 4} \mathbf{g}$ (Schemes 1 and 2) and investigated their potential antidepressant activity using the FST 
and their potential anticonvulsant effect using the maximal electroshock seizure (MES) test as well as their toxicity.

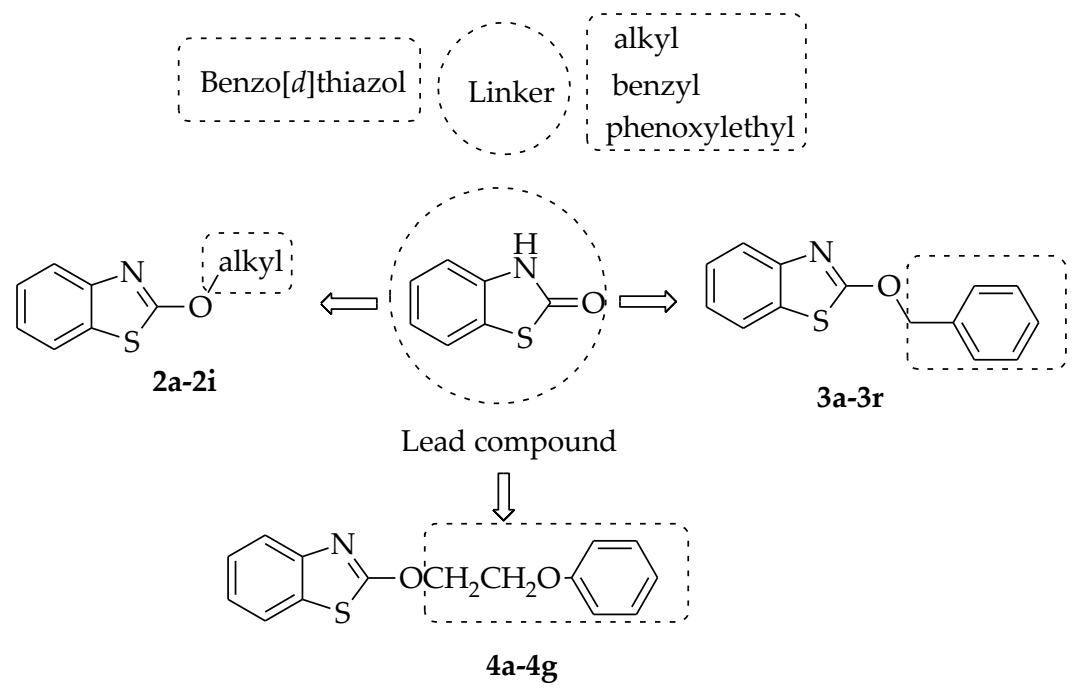

Figure 1. Structures of the lead compounds and derivatives $2 \mathbf{a}-\mathbf{2 i}, \mathbf{3 a}-\mathbf{3 r}$, and $\mathbf{4 a}-\mathbf{4 g}$.

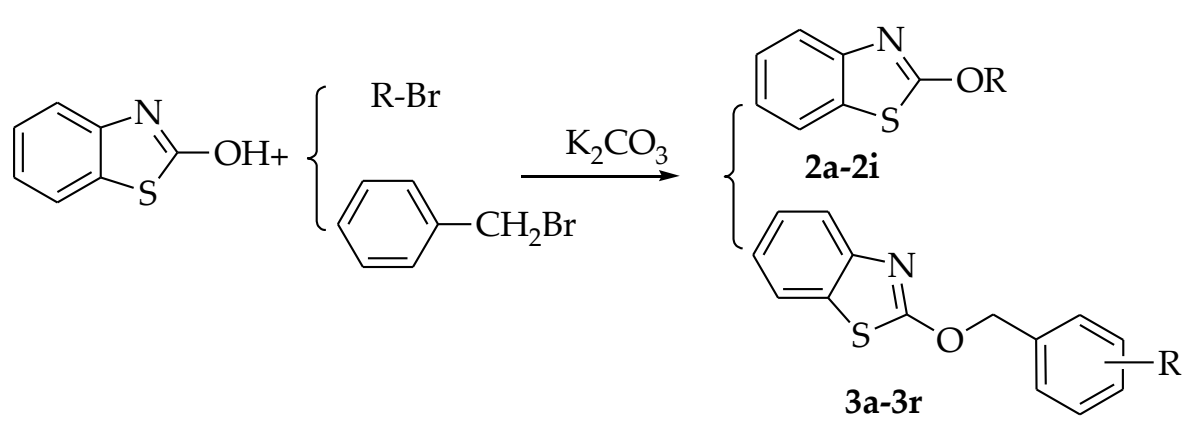

R:

$\begin{array}{lllll}\mathbf{2} \mathbf{a}=-\mathrm{CH}_{2} \mathrm{CH}_{3} & \mathbf{2} \mathbf{b}=-\left(\mathrm{CH}_{2}\right)_{2} \mathrm{CH}_{3} & \mathbf{2} \mathbf{c}=-\left(\mathrm{CH}_{2}\right)_{3} \mathrm{CH}_{3} & \mathbf{2} \mathbf{d}=-\left(\mathrm{CH}_{2}\right)_{4} \mathrm{CH}_{3} & \mathbf{2} \mathbf{e}=-\left(\mathrm{CH}_{2}\right)_{5} \mathrm{CH}_{3} \\ \mathbf{2} \mathbf{f}=-\left(\mathrm{CH}_{2}\right)_{6} \mathrm{CH}_{3} & \mathbf{2} \mathbf{g}=-\left(\mathrm{CH}_{2}\right)_{7} \mathrm{CH} & \mathbf{2} \mathbf{h}=-\left(\mathrm{CH}_{2}\right)_{8} \mathrm{CH}_{3} & \mathbf{2} \mathbf{i}=-\left(\mathrm{CH}_{2}\right)_{9} \mathrm{CH}_{3} & \\ \mathbf{3} \mathbf{a}=-\mathrm{H} & 3 \mathbf{b}=2-\mathrm{F} & 3 \mathbf{c}=3-\mathrm{F} & \mathbf{3 d}=4-\mathrm{F} & 3 \mathbf{e}=2-\mathrm{Cl} \\ \mathbf{3} \mathbf{f}=3-\mathrm{Cl} & \mathbf{3}=4-\mathrm{Cl} & 3 \mathbf{h}=2-\mathrm{Br} & \mathbf{3} \mathbf{i}=3-\mathrm{Br} & 3 \mathbf{j}=4-\mathrm{Br} \\ 3 \mathbf{k}=4-\mathrm{NO}_{2} & 3 \mathbf{l}=4-\mathrm{CN} & \mathbf{3} \mathbf{m}=2-\mathrm{CF}_{3} & \mathbf{3 n}=4-\mathrm{CF}_{3} & \mathbf{3 o}=4-\mathrm{CH}_{3} \\ 3 \mathbf{p}=4-\mathrm{OCH}_{3} & \mathbf{3} \mathbf{q}=3,5-\left(\mathrm{CH}_{3}\right)_{2} & 3 \mathbf{r}=3,5-\left(\mathrm{OCH}_{3}\right)_{2} & & \end{array}$

Scheme 1. Synthesis of $2 \mathbf{a}-2 \mathbf{i}$ and $3 \mathbf{a}-3 \mathbf{r}$.

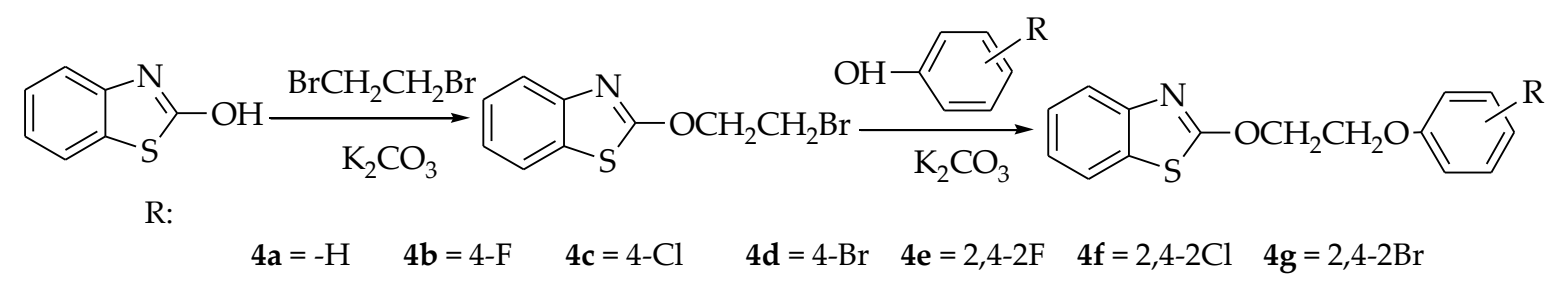

Scheme 2. The synthetic route of derivatives $4 a-4 g$.

\section{Results}

\subsection{Synthesis}

Target compounds $\mathbf{2} \mathbf{a}-\mathbf{2} \mathbf{i}, \mathbf{3 a} \mathbf{a}-\mathbf{3 r}$, and $\mathbf{4 a} \mathbf{a} \mathbf{- 4}$ were prepared as shown in Schemes 1 and 2. Commercially available benzo[d]thiazol-2-ol was the starting material; the derivatives $\mathbf{2 a} \mathbf{a}-\mathbf{2} \mathbf{i}$ and $3 \mathbf{a}-\mathbf{3 r}$ were obtained through the introduction of an alkyl group or benzyl group by a one-step 
nucleophilic substitution reaction. Compounds $4 \mathbf{a}-\mathbf{4 g}$ were obtained through a two-step reaction. The intermediate 2-(2-bromoethoxy)benzo[d]thiazole was synthesized and underwent a nucleophilic substitution reaction with 1,2-dibromoethane, then the 2-(2-bromoethoxy) benzo[ $d]$ thiazole formed was reacted with substituted phenols. The structures of $\mathbf{2 a}-\mathbf{2} \mathbf{i}, \mathbf{3 a}-\mathbf{3 r}$, and $\mathbf{4 a - 4} \mathbf{g}$ were determined by infrared spectrophotometry, ${ }^{1} \mathrm{H}$ and ${ }^{13} \mathrm{C}$ NMR spectroscopy, as well as mass spectrometry.

\subsection{Antidepressant Activity of $\mathbf{2 a}-\mathbf{2} \mathbf{i}, \mathbf{3 a}-\mathbf{3 r}$, and $\mathbf{4 a} \mathbf{-} \mathbf{4} \mathbf{g}$ in the FST}

The antidepressant activity of fluoxetine, $\mathbf{2 a}-\mathbf{2} \mathbf{i}, \mathbf{3 a}-\mathbf{3 r}$, and $\mathbf{4 a}-\mathbf{4 g}$, as indicated by the immobility time in the FST, is displayed in Table 1. Most of the compounds, except for $\mathbf{3 h}, \mathbf{3 k}, \mathbf{3 l}, \mathbf{3 r}, \mathbf{4} \mathbf{c}$, and $4 \mathbf{e}$, induced a significant decrease in the immobility time at $30 \mathrm{mg} \mathrm{kg}^{-1}$ and showed a marked antidepressant effect (Table 1). In particular, $\mathbf{2 b}-\mathbf{2} \mathbf{d}, \mathbf{2} \mathbf{f}$, and $\mathbf{3 q}$ possessed the highest antidepressant effect and induced a significant decrease in the immobility time compared with that of the control group $(p<0.001)$.

Table 1. Antidepressant effect of $2 a-2 i, 3 a-3 r$, and $4 a-4 g$.

\begin{tabular}{|c|c|c|}
\hline \multicolumn{3}{|c|}{ Antidepressant Effect } \\
\hline Compounds & Duration of Immobility (s) & TID $^{a}(\%)$ \\
\hline $2 a$ & $122.5 \pm 9.2 *$ & 31.64 \\
\hline $2 b$ & $59.3 \pm 8.8^{* * *}$ & 66.91 \\
\hline $2 c$ & $18.0 \pm 2.4^{* * *}$ & 89.96 \\
\hline $2 d$ & $18.6 \pm 6.8^{* * *}$ & 89.62 \\
\hline $2 e$ & $104.2 \pm 9.7^{*}$ & 46.32 \\
\hline $2 f$ & $26.7 \pm 7.4^{* * *}$ & 85.10 \\
\hline $2 \mathrm{~g}$ & $67.7 \pm 10.7^{* *}$ & 62.22 \\
\hline $2 \mathrm{~h}$ & $76.0 \pm 13.2 * *$ & 57.59 \\
\hline $2 \mathbf{i}$ & $93.0 \pm 9.0^{* *}$ & 48.10 \\
\hline $3 a$ & $81.2 \pm 9.4^{* *}$ & 54.69 \\
\hline $3 b$ & $84.8 \pm 5.6^{* *}$ & 52.68 \\
\hline $3 c$ & $61.5 \pm 3.3^{* *}$ & 65.68 \\
\hline $3 d$ & $75.2 \pm 8.2 * *$ & 58.04 \\
\hline $3 \mathbf{e}$ & $132.2 \pm 8.5^{*}$ & 26.23 \\
\hline $3 f$ & $68.2 \pm 11.5^{* *}$ & 61.94 \\
\hline $3 g$ & $80.3 \pm 11.9^{* *}$ & 55.19 \\
\hline $3 h$ & $141.3 \pm 8.5$ & 21.15 \\
\hline $3 \mathbf{i}$ & $66.0 \pm 8.1^{* *}$ & 63.17 \\
\hline $3 \mathbf{j}$ & $99.3 \pm 8.7^{* *}$ & 44.59 \\
\hline $3 k$ & $153.8 \pm 11.0$ & 14.17 \\
\hline 31 & $172.5 \pm 5.4$ & 3.74 \\
\hline $3 m$ & $125.8 \pm 13.6 *$ & 29.80 \\
\hline $3 n$ & $124.5 \pm 14.3$ * & 30.52 \\
\hline 30 & $130.6 \pm 5.4 *$ & 27.12 \\
\hline $3 p$ & $71.2 \pm 7.0 * *$ & 60.27 \\
\hline $3 q$ & $26.3 \pm 10.3^{* * *}$ & 85.32 \\
\hline $3 r$ & $143.2 \pm 11.4$ & 20.09 \\
\hline $4 a$ & $67.5 \pm 7.3^{* *}$ & 62.33 \\
\hline $4 b$ & $130.5 \pm 7.9 *$ & 37.56 \\
\hline $4 c$ & $141.7 \pm 9.1$ & 32.20 \\
\hline $4 d$ & $116.2 \pm 7.0 *$ & 44.40 \\
\hline $4 e$ & $151.7 \pm 14.1$ & 27.42 \\
\hline $4 f$ & $129.5 \pm 5.4^{*}$ & 38.04 \\
\hline $4 g$ & $124.2 \pm 8.1 *$ & 40.57 \\
\hline control & $194.1 \pm 11.1$ & - \\
\hline fluoxetine & $31.8 \pm 7.7^{* * *}$ & 83.62 \\
\hline
\end{tabular}

a TID: percentage decrease in immobility duration. Significant differences versus control values. ${ }^{*} p<0.05,{ }^{* *} p<0.01$, *** $p<0.001$. 
To better understand the antidepressant effect of $\mathbf{2 a}-\mathbf{2} \mathbf{i}, \mathbf{3 a}-\mathbf{3 r}$, and $\mathbf{4 a -} \mathbf{- 4} \mathbf{g}$, the percentage reduction in the time of immobility (\% TID) was calculated using the formula

$$
\% \operatorname{TID}=[(X-Y) / X] \times 100
$$

where $\mathrm{X}$ is the immobility time (s) for the control group and $\mathrm{Y}$ is the immobility time (s) for the test group. $\mathbf{2 c}, \mathbf{2 d}, \mathbf{2 f}$, and $\mathbf{3 q}$ reduced the immobility time and showed higher TID values than the other tested compounds (Table 1$)$. The $\%$ TID values for $\mathbf{2 f}(85.10 \%)$ and $\mathbf{3 q}(85.32 \%)$ were similar to that of fluoxetine at a concentration of $30 \mathrm{mg} \mathrm{kg}^{-1}$ in the FST. However, $\mathbf{2 c}$ and $\mathbf{2} \mathbf{d}$ showed higher \% TID values (89.96\% and $89.62 \%$, respectively) than that of fluoxetine ( $83.62 \%)$, suggesting that these compounds may have superior antidepressant effects compared with that of fluoxetine (duration of immobility (s): $2 \mathrm{c}=18.0 \pm 2.4 ; 2 \mathrm{~d}=18.6 \pm 6.8$; fluoxetine $=31.8 \pm 7.7$ ).

\subsection{Anticonvulsant Activity of $\mathbf{2 a - 2 i}, \mathbf{3 a}-\mathbf{3 r}$, and $\mathbf{4 a - 4 g}$ in the MSE Test}

The phase-I test study comprised two parts: MES and toxicity. The toxicity was measured by the rotorod toxicity experiment. Compounds $\mathbf{2 a}-\mathbf{2} \mathbf{i}, \mathbf{3 a}-\mathbf{3 r}$, and $\mathbf{4 a}-\mathbf{4} \mathbf{g}$ were assessed for their anticonvulsant activity. The phase-I test was a qualitative analysis, with three doses of the test compounds administered (30,100, and $\left.300 \mathrm{mg} \mathrm{kg}^{-1}\right)$. A protective effect was observed in mice through intraperitoneal administration of $\mathbf{2} \mathbf{a}-\mathbf{2} \mathbf{i}, \mathbf{3} \mathbf{a}-\mathbf{3 r}$, and $\mathbf{4 a} \mathbf{a}-\mathbf{4} \mathbf{g}$ in the MES test (Table 2). Except for $\mathbf{2} \mathbf{f}-\mathbf{2} \mathbf{i}, \mathbf{3 h}$, $\mathbf{3 j}, \mathbf{3 k}$, $\mathbf{4} \mathbf{a}$ and $\mathbf{4 f}$, other derivatives displayed an anticonvulsant effect. Compounds $\mathbf{2 a}, \mathbf{3} \mathbf{a}, \mathbf{3} \mathbf{1}, \mathbf{3} \mathbf{n}-\mathbf{3} \mathbf{q}$, and $\mathbf{4 b}$ displayed the highest anticonvulsant effect at $30 \mathrm{mg} \mathrm{kg}^{-1}$ in an MES test. Compounds $\mathbf{2 c}-\mathbf{2 e}$, $3 \mathbf{b}, \mathbf{3 e}-\mathbf{3 g}, \mathbf{3 i}, \mathbf{3 m}, \mathbf{3 r}, \mathbf{4 d}, \mathbf{4 e}$ and $4 \mathrm{~g}$ were active at $100 \mathrm{mg} \mathrm{kg}^{-1}$. While $\mathbf{2 b}, \mathbf{3 c}, \mathbf{3 d}$, and $4 \mathrm{c}$ showed the anticonvulsant activity at $300 \mathrm{mg} \mathrm{kg}^{-1}$. The rotorod toxicity experiment indicated that $\mathbf{2 a}-\mathbf{2} \mathbf{i}, \mathbf{3 a}-\mathbf{3 r}$, and $\mathbf{4 a}-\mathbf{4 g}$ did not display toxicity at the test doses. In addition, all compounds were excreted or metabolized in $\sim 4 \mathrm{~h}$.

Table 2. Anticonvulsant activity of $\mathbf{2 a}-\mathbf{2 i}, \mathbf{3 a}-\mathbf{3 r}$, and $\mathbf{4 a}-\mathbf{4} \mathbf{g}$ in a phase-I study.

\begin{tabular}{cccccc}
\hline \multirow{2}{*}{ Compounds } & Dosage $\left(\mathbf{m g} \cdot \mathbf{k g}^{-\mathbf{1}}\right)$ & \multicolumn{2}{c}{$\mathbf{M E S}^{\mathbf{a}}$} & \multicolumn{2}{c}{ Rotorod $^{\mathbf{b}}$} \\
\cline { 3 - 6 } & & $\mathbf{0 . 5} \mathbf{h}$ & $\mathbf{4} \mathbf{h}$ & $\mathbf{0 . 5} \mathbf{h}$ & $\mathbf{4} \mathbf{h}$ \\
\hline $\mathbf{2 a}$ & 30 & $1 / 3$ & $0 / 3$ & $0 / 3$ & $0 / 3$ \\
$\mathbf{2 b}$ & 300 & $1 / 3$ & $0 / 3$ & $0 / 3$ & $0 / 3$ \\
$\mathbf{2 c}$ & 100 & $1 / 3$ & $0 / 3$ & $0 / 3$ & $0 / 3$ \\
$\mathbf{2 d}$ & 100 & $1 / 3$ & $0 / 3$ & $0 / 3$ & $0 / 3$ \\
$\mathbf{2 e}$ & 100 & $1 / 3$ & $0 / 3$ & $0 / 3$ & $0 / 3$ \\
$\mathbf{2 f}$ & 300 & $0 / 3$ & $0 / 3$ & $0 / 3$ & $0 / 3$ \\
$\mathbf{2 g}$ & 300 & $0 / 3$ & $0 / 3$ & $0 / 3$ & $0 / 3$ \\
$\mathbf{2 h}$ & $0 / 3$ & $0 / 3$ & $0 / 3$ & $0 / 3$ \\
$\mathbf{2 i}$ & 300 & $0 / 3$ & $0 / 3$ & $0 / 3$ & $0 / 3$ \\
$\mathbf{3 a}$ & 300 & $1 / 3$ & $0 / 3$ & $0 / 3$ & $0 / 3$ \\
$\mathbf{3 b}$ & 30 & $1 / 3$ & $0 / 3$ & $0 / 3$ & $0 / 3$ \\
$\mathbf{3 c}$ & 100 & $1 / 3$ & $0 / 3$ & $0 / 3$ & $0 / 3$ \\
$\mathbf{3 d}$ & 300 & $3 / 3$ & $0 / 3$ & $0 / 3$ & $0 / 3$ \\
$\mathbf{3 e}$ & 300 & $1 / 3$ & $0 / 3$ & $0 / 3$ & $0 / 3$ \\
$\mathbf{3 f}$ & 100 & $1 / 3$ & $0 / 3$ & $0 / 3$ & $0 / 3$ \\
$\mathbf{3 g}$ & 100 & $0 / 3$ & $0 / 3$ & $0 / 3$ & $0 / 3$ \\
$\mathbf{3 h}$ & 100 & $1 / 3$ & $0 / 3$ & $0 / 3$ & $0 / 3$ \\
$\mathbf{3 i}$ & 300 & $0 / 3$ & $0 / 3$ & $0 / 3$ & $0 / 3$ \\
$\mathbf{3 j}$ & 100 & $0 / 3$ & $0 / 3$ & $0 / 3$ & $0 / 3$ \\
$\mathbf{3 k}$ & 300 & $2 / 3$ & $0 / 3$ & $0 / 3$ & $0 / 3$ \\
$\mathbf{3 1}$ & 300 & $2 / 3$ & $0 / 3$ & $0 / 3$ & $0 / 3$ \\
$\mathbf{3 m}$ & 30 & $3 / 3$ & $0 / 3$ & $0 / 3$ & $0 / 3$ \\
$\mathbf{3 n}$ & 100 & $1 / 3$ & $0 / 3$ & $0 / 3$ & $0 / 3$ \\
$\mathbf{3 0}$ & 30 & & & &
\end{tabular}


Table 2. Cont.

\begin{tabular}{|c|c|c|c|c|c|}
\hline \multirow{2}{*}{ Compounds } & \multirow{2}{*}{ Dosage $\left(\mathrm{mg} \cdot \mathrm{kg}^{-1}\right)$} & \multicolumn{2}{|c|}{ MES $^{a}$} & \multicolumn{2}{|c|}{ Rotorod $^{b}$} \\
\hline & & $0.5 \mathrm{~h}$ & $4 \mathrm{~h}$ & $0.5 \mathrm{~h}$ & $4 \mathrm{~h}$ \\
\hline $3 p$ & 30 & $2 / 3$ & $0 / 3$ & $0 / 3$ & $0 / 3$ \\
\hline $3 q$ & 30 & $3 / 3$ & $0 / 3$ & $0 / 3$ & $0 / 3$ \\
\hline $3 r$ & 100 & $2 / 3$ & $0 / 3$ & $0 / 3$ & $0 / 3$ \\
\hline $4 a$ & 300 & $0 / 3$ & $0 / 3$ & $0 / 3$ & $0 / 3$ \\
\hline $4 b$ & 30 & $1 / 3$ & $0 / 3$ & $0 / 3$ & $0 / 3$ \\
\hline $4 c$ & 300 & $1 / 3$ & $0 / 3$ & $0 / 3$ & $0 / 3$ \\
\hline $4 d$ & 100 & $1 / 3$ & $0 / 3$ & $0 / 3$ & $0 / 3$ \\
\hline $4 e$ & 100 & $1 / 3$ & $0 / 3$ & $0 / 3$ & $0 / 3$ \\
\hline $4 f$ & 300 & $0 / 3$ & $0 / 3$ & $0 / 3$ & $0 / 3$ \\
\hline $4 g$ & 100 & $1 / 3$ & $0 / 3$ & $0 / 3$ & $0 / 3$ \\
\hline Valproate & 100 & $3 / 3$ & $0 / 3$ & $0 / 3$ & $0 / 3$ \\
\hline
\end{tabular}

a MES test (numbers of mice defended/numbers of mice detected); ${ }^{b}$ Toxicity: rotorod test (numbers of mice showing toxicity/numbers of mice detected).

Next, the effect of $\mathbf{2 a}, \mathbf{3} \mathbf{a}, \mathbf{3} \mathbf{b}, \mathbf{3 e}, \mathbf{3} \mathbf{1}, \mathbf{3} \mathbf{n}-\mathbf{3} \mathbf{q}$, and $\mathbf{4 b}$ were evaluated quantitatively for their anticonvulsant activity median effective dose $\left(\mathrm{ED}_{50}\right)$ and neurotoxicity median toxicity dose $\left(\mathrm{TD}_{50}\right)$ (Table 3) in a phase-II experiment. $\mathbf{3 n}$ and $\mathbf{3 q}$ showed the greatest effect, with $\mathrm{ED}_{50}$ values of 46.1 and $64.3 \mathrm{mg} \mathrm{kg}^{-1}$, and protective index (PI) of 6.34 and 4.11, respectively, which were higher than those of phenobarbital and valproate.

Table 3. Anticonvulsant activity of $2 a, 3 a, 3 b, 3 e, 31,3 n-3 q$ and $4 b$ in a phase-II study.

\begin{tabular}{|c|c|c|c|}
\hline Compounds & $\mathrm{ED}_{50}{ }^{\mathrm{a}}(\mathrm{mg} / \mathrm{kg})$ & $\mathrm{TD}_{50}{ }^{\mathrm{b}}(\mathrm{mg} / \mathrm{kg})$ & PI $\left(\mathrm{TD}_{50} / \mathrm{ED}_{50}\right)$ \\
\hline $2 a$ & 90.8 & $>200$ & 3.20 \\
\hline $3 a$ & 105.9 & $>200$ & 2.89 \\
\hline $3 b$ & $>300$ & $>200$ & 1.89 \\
\hline $3 e$ & 147.2 & $>200$ & 2.36 \\
\hline 31 & $>300$ & $>200$ & 2.04 \\
\hline $3 n$ & 46.1 & $>200$ & 6.34 \\
\hline 30 & 84.3 & $>200$ & 3.37 \\
\hline $3 p$ & $>300$ & $>200$ & 1.13 \\
\hline $3 q$ & 64.3 & $>200$ & 4.11 \\
\hline $4 b$ & 74.5 & $>200$ & 3.69 \\
\hline Phenobarbital $^{\mathrm{c}}$ & 21.8 & 69.0 & 3.2 \\
\hline Valproate & 247 & $>200$ & 1.6 \\
\hline
\end{tabular}

${ }^{a} \mathrm{ED}_{50}$ : Median effective dose affording anticonvulsant defense for $50 \%$ animals; ${ }^{\mathrm{b}} \mathrm{TD}_{50}$ : Median toxic dose eliciting minimal neurological toxicity for $50 \%$ animals; ${ }^{c}$ data from Krall et al. 1978 [17].

\subsection{Effects of $\mathbf{2 c}$ and $\mathbf{2} \mathbf{d}$ on Monoamine Levels}

Monoamine concentrations in the mouse brain are shown in Table 4. The concentration of $\mathbf{2 c}$, $2 \mathrm{~d}$, and fluoxetine was $30 \mathrm{mg} \mathrm{kg}^{-1}$. The neurotransmitter concentration was calculated as $\mathrm{ng} g$ per brain region wet weight. $2 \mathrm{c}$ and $2 \mathrm{~d}$ did not alter the dopamine concentration, but increased the concentrations of serotonin and norepinephrine in mouse brain significantly in the FST, and these effects were similar to those of the positive control fluoxetine. 
Table 4. Effect of $2 \mathrm{c}$ and $2 \mathrm{~d}$ on monoamine concentrations in mouse brain.

\begin{tabular}{cccc}
\hline Groups & Serotonin & Norepinephrine & Dopamine \\
\hline Normal Vehicle & $325.1 \pm 28.3^{\mathrm{c}}$ & $298.4 \pm 22.4$ & $357.4 \pm 29.8$ \\
Stress Vehicle & $202.4 \pm 38.4^{\mathrm{c}}$ & $207.3 \pm 25.7^{\mathrm{c}}$ & $218.7 \pm 20.0$ \\
2c & $334.5 \pm 31.9^{\mathrm{b}, \mathrm{c}}$ & $309.5 \pm 20.6^{\mathrm{a}, \mathrm{c}}$ & $201.5 \pm 19.2$ \\
2d & $329.0 \pm 27.8^{\mathrm{b}, \mathrm{c}}$ & $310.7 \pm 24.9^{\mathrm{a}, \mathrm{c}}$ & $206.0 \pm 18.7$ \\
Fluoxetine & $340.3 \pm 32.5^{\mathrm{b}, \mathrm{c}}$ & $321.8 \pm 29.1^{\mathrm{a}, \mathrm{c}}$ & $202.6 \pm 17.8$ \\
\hline
\end{tabular}

Values are given as mean $\pm \operatorname{SEM}(n=8) .{ }^{\mathrm{a}} P<0.05,{ }^{\mathrm{b}} P<0.01$ vs. stress vehicle; ${ }^{\mathrm{c}} P<0.05$ vs. normal vehicle.

\section{Discussion}

The FST is a model of depression. It mimics the condition of hopelessness and has a good predictive validity in mice. In this model, mice are limited in movement and cannot abscond, which results in motionlessness [18]. The immobility displayed in this model has been assumed to correspond to a behavioral response to hopelessness which, in turn, might correspond to a depressive disorder in humans [19].

Nine benzo[ $[d]$ thiazole derivatives (2a-2i) containing an alkyl group with 2-10 carbons displayed antidepressant activity. Among them, $\mathbf{2 c}$ ( $n$-butyl group) and $\mathbf{2 d}$ (n-pentyl group) exhibited the highest antidepressant activity. Although alkyl groups are not a functional group, they can play an important role in the binding interactions of a drug with its target. Alkyl chains are hydrophobic and can interact with the hydrophobic region of a receptor through Van der Waals interaction in the binding site. Varying the size of the group allows exploration of the hydrophobic region [20].

Among 18 benzyloxybenzo[d]thiazole derivatives 3a-3r, most of the compounds, except for $3 \mathbf{h}, 3 \mathbf{k}, 3 \mathbf{l}$ and $3 \mathbf{r}$, induced a significant decrease in the immobility time at $30 \mathrm{mg} \mathrm{kg}^{-1}$ and showed marked antidepressant effect. Interestingly, 3q, which has two methyl substituents on the phenyl ring, displayed the highest antidepressant effect.

However, the reduction conditions needed would be quite harsh and might not be feasible without causing drug degradation [20]. The position of halogen atoms affects antidepressant activity on the phenyl ring.

Comparing the F-substituted compounds $\mathbf{3 b}, \mathbf{3} \mathbf{c}$ and $\mathbf{3} \mathbf{d}$ at different positions on the phenyl ring, the sequence of effect was 3-F $>4-\mathrm{F}>2-\mathrm{F}$, and the sequence of effect for $\mathrm{Cl}$-substituted compounds $3 \mathbf{e}$, $3 \mathbf{f}$, and $\mathbf{3} \mathbf{g}$ was $3-\mathrm{Cl}>4-\mathrm{Cl}>2-\mathrm{Cl}$. The sequence of effect for different $\mathrm{Br}$-substituted compounds $3 \mathbf{h}, \mathbf{3} \mathbf{i}$, and $3 \mathbf{j}$ was $3-\mathrm{Br}>4-\mathrm{Br}>2-\mathrm{Br}$. In addition, among the compounds with electron-withdrawing groups (i.e., $3 \mathbf{k}, 31,3 \mathrm{~m}$, and $3 \mathrm{n}$ ), only $3 \mathrm{~m}$ and $3 \mathrm{n}$ (with a $-\mathrm{CF}_{3}$ group) exhibited the antidepressant activities. For compounds with electron-donating groups, $3 \mathbf{o}-3 \mathbf{r}$, the sequence of activity was 3,5-( $\left(\mathrm{CH}_{3}\right)_{2}>$ $4-\mathrm{OCH}_{3}>4-\mathrm{CH}_{3}>3,5-\left(\mathrm{OCH}_{3}\right)_{2}$. Of seven phenoxylethoxylbenzo[d]thiazole compounds $4 \mathbf{a}-\mathbf{4} \mathbf{g}$, except for $4 \mathrm{c}$ and $4 \mathrm{e}$, the remaining five compounds $4 \mathrm{a}, 4 \mathrm{~b}, 4 \mathrm{~d}, 4 \mathrm{f}$, and $4 \mathrm{~g}$ induced a significant decrease in the immobility time at $30 \mathrm{mg} \mathrm{kg}^{-1}$ and exhibited antidepressant effects. Among them, $4 \mathbf{a}$ displayed the highest antidepressant activity.

Nervous stress can cause impressionable individuals to develop epilepsy, and depressive illness is a general comorbidity related to epilepsy [21]. Nevertheless, understanding the heterogeneity of depression and epilepsy is difficult [22] Antiepileptic drugs might ameliorate the symptoms of depression, as indicated in clinical studies. Curing depression will have positive effects on epilepsy and quality of life.

The anticonvulsant effects of $\mathbf{2 a}-\mathbf{2} \mathbf{i}, \mathbf{3 a} \mathbf{a}-\mathbf{3 r}$, and $\mathbf{4 a} \mathbf{a}-\mathbf{4} \mathbf{g}$ were evaluated using the MES test. The most efficacious compounds, $3 \mathbf{n}$ and $\mathbf{3 q}$, exhibited $\mathrm{ED}_{50}$ values of 46.1 and $64.3 \mathrm{mg} \mathrm{kg}^{-1}$ and had PI values of 6.34 and 4.11, respectively, which were greater than those of phenobarbital or valproate. Therefore, 3n and $\mathbf{3 q}$ might be useful candidates as antidepressant drugs for curing depression in patients with epilepsy.

A disruption in the release of neurotransmitters in the CNS, such as serotonin, norepinephrine, and dopamine, has been proposed to be a characteristic of depression. The metabolic imbalance of 
monoamine transmitters is considered to be a fundamental neurochemical feature in patients with depression. Hence, patients could be treated by increasing monoamine concentrations in the CNS [23]. We found that $\mathbf{2} \mathbf{c}$ and $\mathbf{2 d}$ increased concentrations of serotonin and norepinephrine markedly without altering dopamine concentrations in mouse brains, in a similar manner to that seen with the positive control fluoxetine in the FST. A cure for patients with major depression is deemed to include an increase in levels of serotonin or norepinephrine [24,25]. Thus, the antidepressant activities of $\mathbf{2} \mathbf{c}$ and $\mathbf{2} \mathbf{d}$ could be reflected by measuring levels of serotonin and norepinephrine in the CNS.

\section{Method and Material}

\subsection{Reagents and Instruments}

Positive drug: fluoxetine (purity $>99 \%$ ) was purchased from Sigma. Melting points were measured by the melting point apparatus (WRS-1B, Shanghai, China). Infrared spectra (IR in KBr) were recorded using FT-IR1730 (Bruker, Switzerland). ${ }^{1} \mathrm{H}$ and ${ }^{13} \mathrm{C}$ NMR spectra were recorded on an AV-300 (Bruker, Switzerland), and the chemical shift values are in ppm relative to the TMS or solvent peaks. Mass spectra were recorded on MALDI-TOF/TOF mass spectrometer (Bruker Daltonik, Bremen, Germany). Main reagents were purchased from Aldrich Chemical Corporation (Shanghai, China).

\subsection{Synthesis of Benzo[d]thiazol and Benzyloxybenzo[d]thiazole Derivatives $\mathbf{2 a}-\mathbf{2 i}, \mathbf{3 a - 3 r}$}

A solution of benzo[d]thiazol-2-ol $(3.0 \mathrm{mmol})$, anhydrous $\mathrm{K}_{2} \mathrm{CO}_{3}(3.0 \mathrm{mmol})$ and $5 \mathrm{~mL}$ DMF was stirred in a round-bottomed flask for $1 \mathrm{~h}$ at $60^{\circ} \mathrm{C}$, then, $1.2 \mathrm{mmol}$ of alkyl bromide or substituted brominated benzyl compound was added slowly to the reaction solution. The reaction solution was refluxed for $5 \mathrm{~h}$, the reaction was monitored by TLC. DMF was evaporated under reduced pressure, the residue was washed with water, filtered, dried and the crude product was crystallized from $\mathrm{MeOH}$. The yield, melting point, and spectral data of each compound are given below.

\subsection{Synthesis of Ethoxylbenzo[d]thiazole Derivatives $4 a-4 g$}

A mixture of benzo[d]thiazol-2-ol ( $3.0 \mathrm{mmol}, 0.5 \mathrm{~g}), 1,2$-dibromoethane $(3.0 \mathrm{mmol}, 0.6 \mathrm{~g})$ and anhydrous $\mathrm{K}_{2} \mathrm{CO}_{3}(3.0 \mathrm{mmol}, 0.4 \mathrm{~g})$ was refluxed in DMF for $1 \mathrm{~h}$, after the completion of the reaction (as monitored by TLC), DMF was evaporated and the precipitated product was washed with deionized water, dried. Then, 2-(2-bromoethoxy)benzo[d]thiazole $(3.0 \mathrm{mmol}, 0.8 \mathrm{~g}), 10 \mathrm{~mL}$ of a mixture of $\mathrm{NaOH}$ and substituted phenol was refluxed in $\mathrm{EtOH}$ for $2-5 \mathrm{~h}$. After the completion of the reaction (as monitored by TLC), the solution was filtered and washed with $10 \% \mathrm{HCl}$ and water. The crude product was recrystallized from $\mathrm{MeOH}$. The melting points, yields, and spectral data of $\mathbf{4 a} \mathbf{- 4} \mathbf{g}$ are given below.

\subsection{Experimental Animal and Compounds Treatment}

Male ICR mice ( $20 \pm 2 \mathrm{~g}$ ) were purchased from the laboratory of animal study of Zhejiang Academy of medical sciences. Before the experiment started, mice were tamed for 1 week. During and before the test, mice were kept at $23 \pm 2{ }^{\circ} \mathrm{C}$ for $12 \mathrm{~h}$, at day and night circle, and tap water and standard food granules were provided. The procedures were adopted according to the National Institute of Health Guide for the Care and Use of Laboratory Animals and approved by the Ethics Committee of our Institution in this study. All the test compounds were dissolved in PEG-400 (polyethylene glycol-400). Other drugs were dissolved in $0.9 \% \mathrm{NaCl}$ (isotonic saline solution). Fluoxetine, phenobarbital, and valproate were used as positive controls and the vehicle as the negative control. All the test compounds and other drugs were administered intraperitoneally for $30 \mathrm{~min}$ in the FST, the volume of the drug solution and vehicle was $0.1 \mathrm{~mL} / 20 \mathrm{~g}$ of mice.

\subsection{In the FST}

Male ICR mice were randomized into groups. On the day of the experiment, mice were placed one at a time into a Perspex barrel (elevation $20 \mathrm{~cm}, 10 \mathrm{~cm}$ diameter) including $10 \mathrm{~cm}$ water about 
$22{ }^{\circ} \mathrm{C}$. Mice were arranged into different groups $(n=8)$. Next, a mouse was placed independently into the perspex barrel and kept in the water for six minutes. After two minutes of fierce struggle, the mice were immobile. The duration of immobility was recorded during the last four min of the six min test. The immobility course was treated as the time that the mice floating on the water without struggle and maintained only the movements necessary to provide their head above the water [26,27].

\subsection{In the MES Experiment}

Convulsions were initiated in mice with a $60 \mathrm{~Hz}$ alternating current for $50 \mathrm{~mA}$. The electric current was implemented via corneal electrodes for $0.3 \mathrm{~s}$. Protection against the spread of the maximal electroshock seizure-induced seizures was defined as the abolition of the hind leg and tonic maximal extension component of the seizure. At $30 \mathrm{~min}$ after the administration of the compounds, the activity was evaluated in the maximal electroshock seizure test [28].

\subsection{Experiment of Neurotoxicity}

The neurotoxicity experiment of the compounds and drugs was evaluated through the rotorod experiment in mice. The mice were trained to stay on an accelerating rotorod of diameter $3.2 \mathrm{~cm}$ that rotated at $10 \mathrm{rpm}$. Trained animals were given an intraperitoneal injection of the test compounds. Neurotoxicity was indicated by the inability of the animal to maintain equilibrium on the rod for at least $1 \mathrm{~min}$ in each of the trials. The MES and rotorod tests were carried out according to the standard procedure described in the Antiepileptic Drug Development Program (ADD) of the National Institutes of Health (USA) [29].

\subsection{HPLC conditions and Sample Preparation}

The dosage of $30 \mathrm{mg} \mathrm{kg}^{-1}$ of $\mathbf{2} \mathbf{b}, \mathbf{2} \mathbf{c}$ and fluoxetine was used for testing the action on MOA neurochemical levels in rat brain. Mice were randomly divided into five groups $(n=10) . \mathbf{2} \mathbf{b}, \mathbf{2} \mathbf{c}$ and fluoxetine, normal vehicle, stress vehicle oral gavage once a day for seven days. After the end of the test, the mouse was immediately sacrificed by cervical dislocation, then the brain tissue was immediately removed, and quickly frozen and at $-80^{\circ} \mathrm{C}$ until used for neurochemical analysis. The brain tissues were sonicated in $0.1 \mathrm{M} \mathrm{NaH}_{2} \mathrm{PO}_{4}$ aqueous solution including $0.85 \mathrm{mM}$ OSA, $0.5 \mathrm{mM} \mathrm{Na} 2$.EDTA (ethylenediamine tetraacetic acid disodium), centrifuged at $13,000 \times g$ at $4{ }^{\circ} \mathrm{C}$ for 15 minutes. Then serotonin, norepinephrine and dopamine were analyzed by High-Performance Liquid chromatography coupled with an electron capture detector. The mobile phase was made up of $0.1 \mathrm{~mol} \mathrm{~L}^{-1}$ anhydrous sodium dihydrogen phosphate containing $0.5 \mathrm{mM}$ EDTA and $0.85 \mathrm{mM}$ osanetant (OSA) and $11 \% \mathrm{MeOH}$ and regulated to $\mathrm{pH} 3.4$ using phosphate acid buffer solution and filtered by the pore size ultrafiltration membrane of $0.45 \mu \mathrm{M}$. The external standard curves were used to quantify the amounts of serotonin, noradrenaline, and dopamine in each sample calculated by area under the curve. The injection volume dose was $20 \mu \mathrm{L}$. The detection limit of the analysis was $20 \mathrm{pg} \cdot \mathrm{g}^{-1}$ sample.

\subsection{Statistic Analysis}

All analyses were performed using the GraphPad Prism program (GraphPad software, Inc., San Diego, CA, USA). The statistical analysis of the behavioral tests was performed by analysis of variance (ANOVA), which was followed by Tukey's post hoc comparison test. All experimental results are presented as mean (s) \pm standard error of the mean (SEM), with a $p$-value smaller than 0.05 considered statistically significant.

\section{Conclusions}

Thirty-four previously unreported benzo[ $d]$ thiazol derivatives $\mathbf{2 a}-\mathbf{2 i}, \mathbf{3 a}-\mathbf{3 r}$, and $\mathbf{4 a} \mathbf{a}-\mathbf{4} \mathbf{g}$ were prepared and assessed for their potential antidepressant and anticonvulsant effects. $2 \mathbf{c}$ and $\mathbf{2 d}$ decreased the immobility time markedly and displayed the highest antidepressant effects in the FST, and also showed 
anticonvulsant activity. $2 \mathrm{c}$ and $\mathbf{2 d}$ did not change the dopamine concentration but increased the concentrations of serotonin and norepinephrine significantly in the mouse brain in the FST, similar to that observed with the positive control fluoxetine. These results suggest that $2 \mathrm{c}$ and $2 \mathrm{~d}$ may be potential leads for the development of therapeutic agents for the treatment of depression and epilepsy.

Author Contributions: L.G. and H.J. designed the research and conducted the animal experiments in the study. Q.J. and Z.F. discussed the pharmacological results in this study. The test data were gathered by Z.F. Q.J. and L.G. performed the synthetic work. The manuscript was written by L.G. and H.J. All authors discussed, edited and approved the final version.

Funding: This study was financially supported by the National Natural Science Foundation of China (No. 81560149; No. 81760207).

Acknowledgments: We thank Si-Hong Wang from Yanbian University, China, for spectral testing and spectral analysis of compounds of this manuscript. Victoria Muir and Koji Yamashita from Liwen Bianji, Edanz Group China (www.liwenbianji.cn/ac), edited the English text of a draft of this manuscript.

Conflicts of Interest: The authors declare no conflict of interest.

\section{References}

1. Tan, R.W. Marine microorganisms: An important source of new natural drugs. Chin. J. Nat. Med. 2006, 4, 2-4.

2. Shang, X.H.; Liu, X.Y.; Zhang, J.P.; Gao, Y.; Jiao, B.H.; Zheng, H.; Lu, X.L. Traditional Chinese medicine-sea urchin. Mini Rev. Med. Chem. 2014, 14, 537-542. [CrossRef] [PubMed]

3. Zhou, Y.; Li, Y.H.; Yu, H.B.; Liu, X.Y.; Lu, X.L.; Jiao, B.H. Furanone derivative and sesquiterpene from Antarctic marine-derived fungus Penicillium sp. S-1-18. J. Asian Nat. Prod. Res 2018, 2012, 1108-1115. [CrossRef] [PubMed]

4. Leleu-Chavain, N.; Baudelet, D.; Heloire, V.M.; Rocha, D.E.; Renault, N.; Barczyk, A.; Djouina, M.; Body-Malapel, M.; Carato, P.; Millet, R. Benzo[d]thiazol-2(3H)-ones as new potent selective $\mathrm{CB}_{2}$ agonists with anti-inflammatory properties. Eur. J. Med. Chem. 2019, 165, 347-362. [CrossRef] [PubMed]

5. Cindrić, M.; Perić, M.; Kralj, M.; Martin-Kleiner, I.; David-Cordonnier, M.H.; Paljetak, H.Č.; Matijašić, M.; Verbanac, D.; Karminski-Zamola, G.; Hranjec, M. Antibacterial and antiproliferative activity of novel 2-benzimidazolyl-and 2-benzothiazolyl-substitutedbenzo[b]thieno-2-carboxamides. Mol. Div. 2018, 22, 637-646. [CrossRef] [PubMed]

6. Akhtar, T.; Hameed, S.; Al-Masoudi, N.A.; Loddo, R.; La Colla, P. In vitro antitumor and antiviral activities of new benzothiazole and 1,3,4-oxadiazole-2-thione derivatives. Acta Pharm. 2008, 58, 135-149. [CrossRef] [PubMed]

7. Nagararaju, G.; Sai, K.B.; Chandana, K.; Guldipati, M.; Suresh, P.V.; Ramarao, N. Synthesis, evaluation of antioxidant and antimicrobial study of 2-substituted benzothiazole derivatives. Indo Am. J. Pharm. Res. 2015, 5, 1288-1296.

8. Khan, K.M.; Mesaik, M.A.; Abdalla, O.M.; Rahim, F.; Soomro, S.; Halim, S.A.; Mustafa, G.; Ambreen, N.; Khalid, A.S.; Taha, M. The immunomodulation potential of the synthetic derivatives of benzothiazoles: Implications in immune system disorders through in vitro and in silico studies. Bioorg. Chem. 2016, 64, $21-28$. [CrossRef]

9. Tripathi, R.K.; Ayyannan, S.R. Design, Synthesis, and evaluation of 2-amino-6-nitrobenzothiazole-derived hydrazones as MAO inhibitors: Role of the methylene spacer group. ChemMedChem 2016, 11, 1551-1567. [CrossRef]

10. Tripathi, R.K.; Goshain, O.; Ayyannan, S.R. Design, synthesis, in vitro MAO-B inhibitory evaluation, and computational studies of some 6-nitrobenzothiazole-derived semicarbazones. ChemMedChem 2013, 8, 462-474. [CrossRef]

11. Kaya, B.; Sağlık, B.N.; Levent, S.; Özkay, Y.; Kaplancıklı, Z.A. Synthesis of some novel 2-substituted benzothiazole derivatives containing benzylamine moiety as monoamine oxidase inhibitory agents. J. Enzym. Inhib. Med. Chem. 2016, 31, 1654-1661. [CrossRef] [PubMed]

12. Demir Özkay, Ü.; Kaya, C.; Acar Çevik, U.; Devrim Can, Ö. Synthesis and antidepressant activity profile of some novel benzothiazole derivatives. Molecules 2017, 22, 1490-1504. [CrossRef] [PubMed]

13. Keri, R.S.; Quintanova, C.; Marques, S.M.; Esteves, A.R.; Cardoso, S.M.; Santos, M.A. Design, synthesis and neuroprotective evaluation of novel tacrine-benzothiazole hybrids as multi-targeted compounds against Alzheimer's disease. Bioorg. Med. Chem. 2013, 21, 4559-4569. [CrossRef] [PubMed] 
14. Liu, D.C.; Zhang, H.J.; Jin, C.M.; Quan, Z.S. Synthesis and biological evaluation of novel benzothiazole derivatives as potential anticonvulsant agents. Molecules 2016, 21, 1635-1652.

15. Wang, S.; Chen, Y.; Zhao, S.; Xu, X.; Liu, X.; Liu, B.F.; Zhang, G. Synthesis and biological evaluation of a series of benzoxazole/benzothiazole-containing 2,3-dihydrobenzo[b][1,4] dioxine derivatives as potential antidepressants. Bioorg. Med. Chem. Lett. 2014, 24, 1766-1770. [CrossRef] [PubMed]

16. Siddiqui, N.; Rana, A.; Khan, S.A.; Ahsan, W.; Alam, M.S.; Ahmed, S. Analgesic and antidepressant activities of benzothiazole-benzamides. Biomed. Pharm. J. 2008, 1, 297-300.

17. Krall, R.L.; Penry, J.K.; White, B.G.; Kupferberg, H.J.; Swinyard, E.A. Antiepileptic drug development: II. Anticonvulsant drug screening. Epilepsia 1978, 19, 409-428. [CrossRef] [PubMed]

18. Borsini, F.; Voltera, G.; Meli, A. A dose the behavioral 'despair' test measure 'despair'. Physiol. Behav. 1986, 38, 385-389. [CrossRef]

19. Zhen, X.H.; Quan, Y.C.; Jiang, H.Y.; Wen, Z.S.; Qu, Y.L.; Guan, L.P. Fucosterol, a sterol extracted from Sargassum fusiforme, shows antidepressant and anticonvulsant effects. Eur. J. Pharmacol. 2015, 768, 131-138. [CrossRef] [PubMed]

20. Patrick, G. Instant Notes in Medicinal Chemistry; The United Kingdom BIOS Scientific Publishers Limited: Cambridge, UK, 2001; Volume 3, p. 119.

21. Drinovac, M.; Wagner, H.; Agrawal, N.; Cock, H.R.; Mitchell, A.J.; von Oertzen, T.J. Screening for depression in epilepsy: A model of an enhanced screening tool. Epilepsy Behav. 2015, 44, 67-72. [CrossRef]

22. Fiest, K.M.; Patten, S.B.; Altura, K.C.; Bulloch, A.G.; Maxwell, C.J.; Wiebe, S.; Macrodimitris, S.; Jetté, N. Patterns and frequency of the treatment of depression in persons with epilepsy. Epilepsy Behav. 2014, 39, 59-64. [CrossRef] [PubMed]

23. Hao, C.W.; Lai, W.S.; Ho, C.T.; Sheen, L.Y. Antidepressant-like effect of lemon essential oil is through a modulation in the levels of norepinephrine, dopamine, and serotonin in mice: Use of the tail suspension test. J. Funct. Foods 2013, 5, 370-379. [CrossRef]

24. Xu, J.; Xu, H.; Liu, Y.; He, H.; Li, G. Vanillin-induced amelioration of depression-like behaviors in rats by modulating monoamine neurotransmitters in the brain. Psychiatry Res. 2015, 225, 509-514. [CrossRef] [PubMed]

25. Guan, L.P.; Liu, B.Y. Antidepressant-like effects and mechanisms of flavonoids and relatedanalogues. Eur. J. Med. Chem. 2016, 121, 47-57. [CrossRef] [PubMed]

26. Porsolt, R.D.; Bertin, A.; Jalfre, M. Behavioural despair in mice: Aprimary screening test for antidepressants. Arch. Int. Pharmacodyn. 1997, 229, 327-336.

27. Zhao, D.H.; Wang, Y.C.; Zheng, L.W.; Liu, B.Y.; Guan, L.P. Antidepressant-like effect of a chalcone compound, DHIPC and itspossible mechanism. Iran. J. Pharm. Res. 2018, 17, 193-201.

28. Porter, R.J.; Cereghino, J.J.; Gladding, G.D.; Hessie, B.J.; Kupferberg, H.J.; Scoville, B.; White, B.G. Antiepileptic drug developmentprogram. Cleve Clin. Q. 1984, 51, 293-305. [CrossRef]

29. Guan, L.P.; Quan, Z.S. 3,4-DHQLO and triazole and its related analogues with anticonvulsant effects. Mini Rev. Med. Chem. 2016, 16, 323-342. [CrossRef]

(C) 2019 by the authors. Licensee MDPI, Basel, Switzerland. This article is an open access article distributed under the terms and conditions of the Creative Commons Attribution (CC BY) license (http://creativecommons.org/licenses/by/4.0/). 